\title{
COMPOSITE RESIN RESTORATION WITH FIBER REINFORCED COMPOSITE AFTER ROOT CANAL TREATMENT OF NECROTIC PULP TOOTH WITH GUMBOIL

\begin{abstract}
PEMULIHAN RESIN KOMPOSIT DENGAN KOMPOSIT YANG DIPERKUAT SERAT SETELAH PERAWATAN KANAL ROOT GIGI PULP NEKROTIK DENGAN GUMBOIL
\end{abstract}

\author{
${ }^{1}$ Dessy Natalia and Yulita Kristanti ${ }^{2}$ \\ Department of Conservative Dentistry \\ Faculty of Dentistry of Universitas Gadjah Mada \\ Submitted:20-11-2018; Revised: 02-11-2019; Accepted: 25-06-2021
}

\begin{abstract}
ABSTRAK
Gumboil merupakan reaksi inflamasi pada gusi yang berasal dari infeksi pulpa gigi. Gumboil berupa lesi oral yang ditandai dengan papula kemerahan lunak yang merupakan drainase abses periapikal ke dalam rongga mulut. Perawatan saluran akar yang adekuat dapat menyembuhkan gumboil serta dapat menghilangkan bakteri dari dalam saluran akar. Untuk menunjang keberhasilan perawatan, restorasi akhir yang digunakan pada kasus ini adalah tumpatan resin komposit dengan penguat fiber (short fiber reinforced composite). Perawatan ini bertujuan untuk mengembalikan fungsi gigi dari segi mastikasi dan perlindungan jaringan pendukung gigi. Seorang pasien wanita berusia 23 tahun datang dengan keluhan sakit pada gigi geraham belakang kanan bawah disertai pembengkakan pada gusi di sekitar gigi tersebut sejak seminggu yang lalu. Pembengkakan sering hilang timbul sejak tiga bulan terakhir. Gigi tersebut pernah dilakukan penumpatan sekitar tiga tahun yang lalu. Pemeriksaan klinis menunjukkan perkusi positif, palpasi positif, vitalitas negatif, dan mobilitas negatif. Pemeriksaan radiografi tampak adanya lesi pada bifurkasi dan periapikal. Perawatan saluran akar dilakukan dengan preparasi saluran akar teknik crown down yang diisi dengan gutta percha dan sealer yang dilanjutkan dengan restorasi resin komposit kavitas kelas I dengan penguat short fiber reinforced composite. Keberhasilan perawatan saluran akar dengan restorasi resin komposit disertai dengan penguat short fiber reinforced composite ditandai dengan tidak ada keluhan serta menghilangnya gumboil.
\end{abstract}

Kata Kunci: Gumboil; Gigi; Palpasi positif; Perawatan saluran akar; Short fiber reinforced composite.

\begin{abstract}
Gumboil is inflammation reaction in the gum caused by pulp infection. Gumboil is seen as an oral lesion characterized by a soft erythematous papule where a periapical abcess is draining into the oral cavity. An adequate root canal treatment can cure gumboil and remove bacteria from the root canal. To support the success of root canal treatment, final restoration used in this case is composite resin restoration with reinforcing fiber (short fiber reinforced composite). The purpose of this treatment was to restore the functions of tooth in mastication and preserving the supporting tissue. A female patient age 23 years old came with complaints of pain in the lower
\end{abstract}

*Corresponding author:natalia.deecy24@gmail.com.

Copyright $\odot 2021$ THE AUTHOR(S).This article is distributed under a Creative Commons Attribution-Share Alike 4.0 International license. Jurnal Teknosains is published by the Graduate School of Universitas Gadjah Mada. 
right mandibular molar accompanied by swelling of the gums around the teeth since a week ago. Swelling is intermittent since last three months. The tooth have been restored for about 3 years ago. Clinical examination showed a positive percussion, positive palpation, negative vitality, and negative mobility. Radiographic examination showed bifurcation and periapical lesions. Root canal treatment is performed with crown down preparation technique and followed by direct composite resin restoration with short fiber reiforced composite. The success of root canal treatment followed by composite resin restoration with short fiber reinforced fiber is marked by the absence of complaints as well as the dissappearance of gumboil.

Keywords: Gumboil; Positive palpation; Root canal treatment; Short fiber reinforced composite; Tooth.

\section{INTRODUCTION}

Root canal treatment is a treatment for pulp tissue which is inflamed or necrotic so the tooth can be kept and have function in the oral cavity (Hui et.al., 2004). The success of root canal treatment is indicated from the disappearance of the whole infected pulp tissues, debris, bacteria, and endotoxins from the root canals. Metabolism products from bacteria in the root canals can disseminate in the periapical tissue and cause inflammation response in the periapical (Johnson, 2011).

One of the inflammation responses happens is chronical periapical abscess. Chronical periapical abscess is a sustainable inflammation towards the irritated pulp which occurs on the periapical tissue. It is usually characterized by the existence of gumboil or the formation of active pus with drainage through oral cavity and the existence of fistula or sinus tract (Tarigan and Tarigan, 2012). The gumboil formed is a drainage medium of chronical infections of the periapical through gingiva. This lesion is bordered with epithelium and comes directly from the infection source to the opening called as stoma. Periapical infection with gumboil usually does not cause pain to the patients because there is an exertion of infectious exudate. Stoma can be located in the buccal or lingual areas depending on the direction of tooth apex towards cortical bone (Cohen and Hargreaves, 2011).
In this case, the treatment performed was root canal treatment with composite resin restoration and short fiber reinforced composite. Prognosis depends on the appropriate cleaning and formation of the root canals and hermetic obturation. Other factors like the condition of the periodontal and the rest of the tooth which can be restored can also help determine the prognosis (Grossman et.al., 1995).

\section{Case}

A-23-year old patient came and complained that she had problem with her lower right molar with swollen gum around the tooth since last week. The swelling frequently appeared since the last three months. The tooth had been restorated around three years ago. The patient wanted the tooth to be treated.

In the objective examination on the tooth 46 (Figure 1A), the composite resin restoration of class I can be seen on the tooth occlusal surface with secondary caries and gumboil on the mucosa surface next to the buccal. Clinical examination showed positive percussion, positive palpation, negative vitality and negative mobility. The patient's oral hygiene was good indicated by 0.67 of OHI-S score. The relation of class I angle occlusion was with $2 \mathrm{~mm}$ overjet and $2.5 \mathrm{~mm}$ over bite. The radiography examination (Figure 1B) showed the anatomy shape of the roots and the straight root canals and there was a radiolucent area on bifurcation and periapical.

The diagnosis in this case was a secondary caries with necrotic pulp, symptomatic apical periodontitis and chronical apical abscess. The treatment plans were dental health education (DHE), root canal treatment, and class I composite resin restoration and short fiber reinforced composite in the pulp chamber. The prognosis of this case was good.

On the first visit, subjective, objective, and radiographic examinations were carried out and diagnosis, treatment plans, and documentation were done. The cleaning of old composite resin restoration was done by using diamond round bur (Mani, Mani inc., 
DESSY NATALIA AND YULITA KRISTANTI \& COMPOSITE RESIN RESTORATION WITH FIBER REINFORCED COMPOSITE AFTER ROOT CANAL TREATMENT OF NECROTIC ...

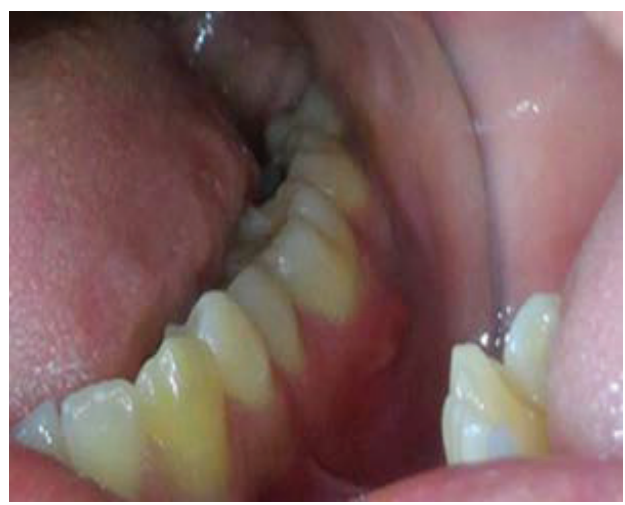

A

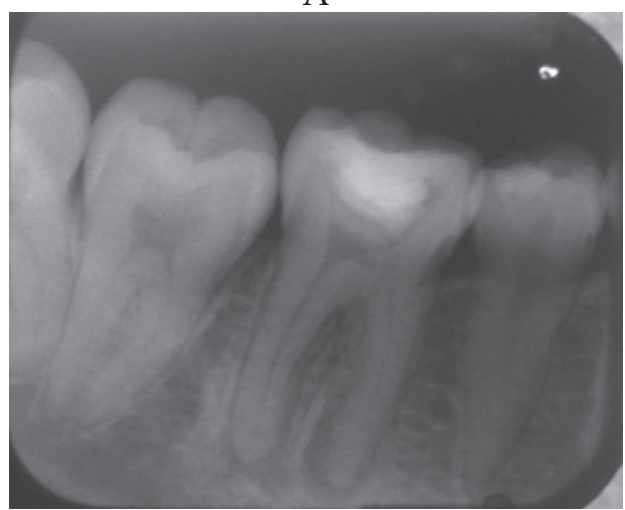

B

Figure 1

A. Gumboil on the buccal mucosa of tooth 46 ;

B. Radiolucent in the bifurcation and periapical of tooth 46

Source: Personal Documentation (2018)

Japan). The caries tissues were cleaned by using metal bur and excavator. Opening access was done with endoacces bur (Dentsply) up to the depth of the pulp chamber reaching the orifice. Then, it was continued by using diamendo (Dentsply) to make wider entry access to the orifice. Irrigation was done with $2.5 \mathrm{ml}$ of $\mathrm{NaOCl} 2.5 \%$ in the cavity and orifice which had been opened (mesiobuccal, mesiolingual, and distal).

The measurement of estimated working length was done from the radiography which was reduced by $1 \mathrm{~mm}$, so there were found the root canals of $20.5 \mathrm{~mm}$ mesiobuccal, 19 $\mathrm{mm}$ mesiolingual, and $20 \mathrm{~mm}$ distal. The exploration and negotiation of the root canals were done using K-file \#8, \#10, \#15 which were inserted to the root canals with the twothird depth of the estimated working length.
The preparation for the root canals was done by using crown down technique using Protaper Hand Use (Dentsply). The preparation was started by coronal flaring of twothird of the estimated working length using file S1 and S2 (13.6 mm mesiobuccal, 12.6 $\mathrm{mm}$ mesiolingual, and $13.3 \mathrm{~mm}$ distal). The measurement of the real working length with K-File \#8, \#10, \#15 used apex locator which was later confirmed with radiography so the real working length was obtained for 20,5 $\mathrm{mm}$ mesiobuccal, $19 \mathrm{~mm}$ mesiolingual, and $20 \mathrm{~mm}$ distal (Figure 2)

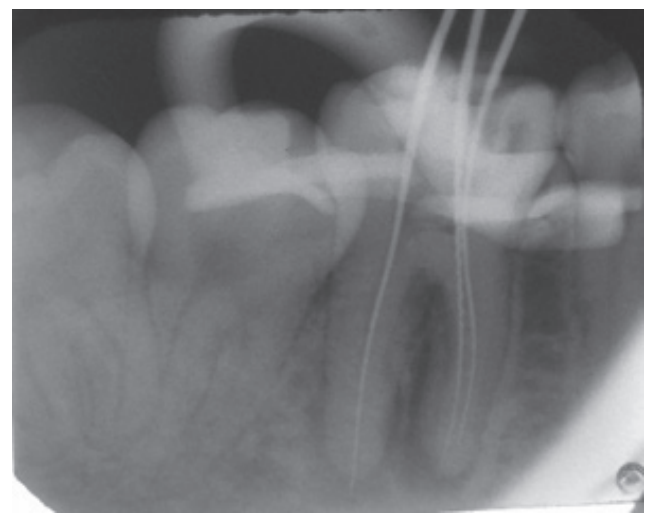

Figure 2.

The measurement of the working length by radiography

Source: Personal Documentation (2018)

Root canal treatment was continued by preparation of distal root canal with protaper hand use until F2 and ended with K-file \#25 based on the working length of $20 \mathrm{~mm}$. The preparation for the mesiobuccal and mesiolingual was up to F1 and ended with K-file \#20 based on the working length of $20.5 \mathrm{~mm}$ for mesiobuccal and $19 \mathrm{~mm}$ for mesioligual. Every time the file changed, the root canals were irrigated with liquid of $\mathrm{NaOCl} 2,5 \%$ and salin. After the preparation of the root canals had finished, the root canals were irrigated using sodium hipochloride ( $\mathrm{NaOCl}$ ) 2,5\%, Ethylene Diamine Tetraacetic Acid (EDTA) 17\% and chlorhexidine $2 \%$. All root canals were later dried with paper point and intracanal medication was done with $\mathrm{Ca}(\mathrm{OH}) 2$ which was mixed with glycerin and were temporarily restorated with cavit (Caviton, GC). 
In the second visit, subjective examination was done and there was no complaints from the patient (there was no pain between the visits). The objective examination indicated good temporary restoration, disappearance of gumboil, negative percussion test, negative palpation test and negative mobility. The use of rubber dam for isolation and temporary restoration was opened using round diamond bur. It was irrigated with $\mathrm{NaOCl} 2.5 \%$ to dissolve $\mathrm{Ca}(\mathrm{OH}) 2$ and dried with paper point. The fitting of gutta percha (Protaper, Dentsply) was carried out according to the working length, namely F1 for mesiobuccal and mesiolingual canals and F2 for distal canal. After that, a radiographic photo was taken. Guta perca seemed fitted to the root canals, so the single cone filling technique was choosen (Figure 3).

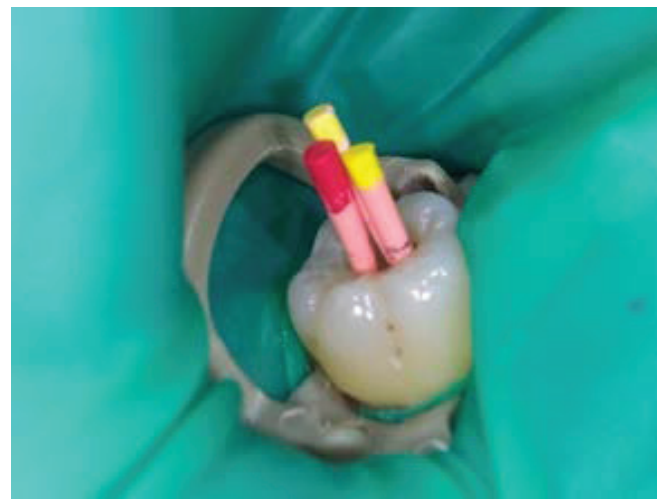

A

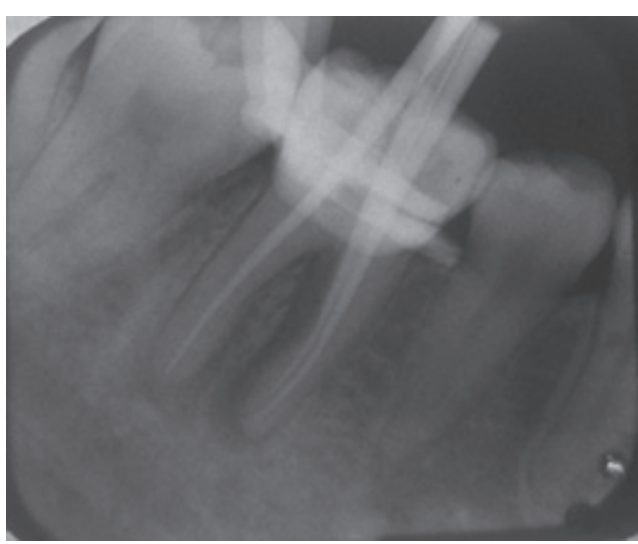

B

Figure 3

A. The fitting of guta perca;

B. The fitting of gutaperca by radiography Source: Personal Documentation (2018)
Root canals were irrigated again using the liquids of NaOCL 2,5\%, EDTA $17 \%$, and Clorhexidine $2 \%$. All root canals were dried with paper point. Gutta percha point was sterilized and soaked in the liquid of $\mathrm{NaOCl}$ $2,5 \%$ for 1 minute, rinsed with alcohol $70 \%$ and dried. Obturation with single cone technique was choosen. First, a lentulo which was already smeared with pasta sealer (Topseal, Dentsply) was inserted and spinned with into the root canal and one third of the apical guta perca was smeared with sealer and inserted into the root canal. The obturation was done in the root canal one by one. The rest of the gutta percha was cut using endodontic plugger which had been heated as long as the orifice and condensed with light press. The result of the root canal filling was confirmed by radiography. The result of the obturation showed hermetic filling (Figure 4). The bottom of the cavity was closed by glass ionomer cement and temporarily restorated with cavit (Cavitron, GC).

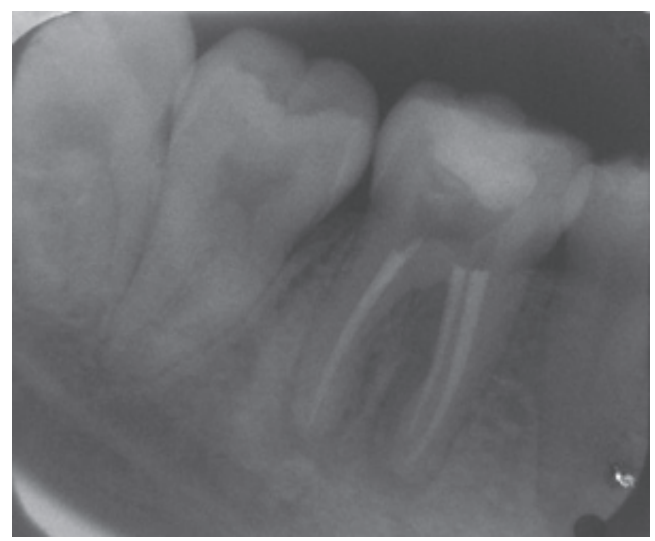

Figure 4.

Radiographic illustration of hermetic filling Source: Personal Documentation (2018)

The third visit was a check-up after the root canal filling. There was no complaint from the patient and there was no pain between the visit time. Temporary restoration was still good, gumboil disappeared, percussion, palpation, and mobility was negative. Radiographic examination still showed the illustration of radiolucent in bifurcation area (Figure 5). 


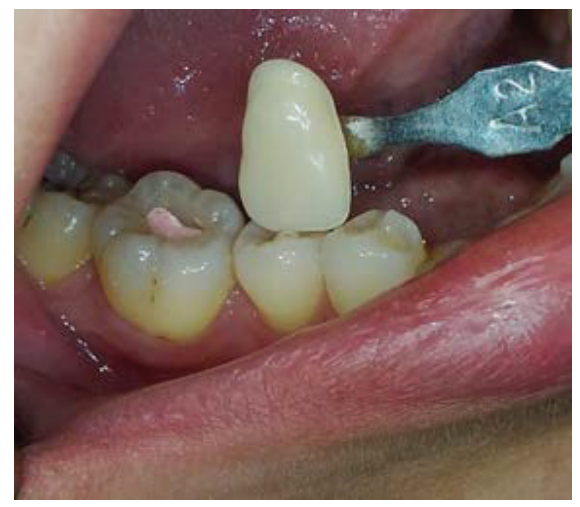

A

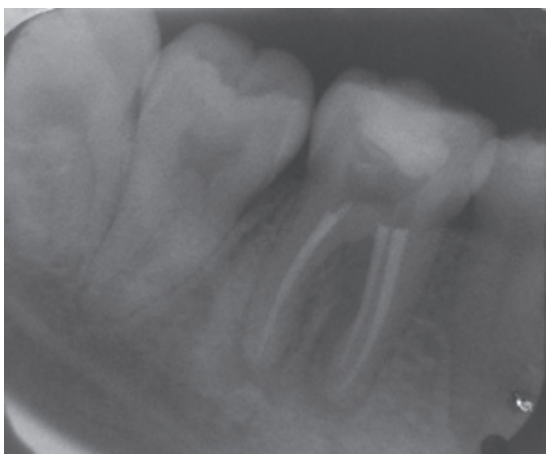

B

Figure 5.

A. The gumboil has disappeared;

B. The radiographic picture of radiolucent area Source: Personal Documentation (2018)

It is continued by Class I composite resin restoration with short fiber reinforced composite. Adjustment of composite resin color, the use of rubber dam for isolation and dismantling the temporary restoration with round diamond bur and excavator were done. Preparation in the occlusal area for Class I composite resin restoration with short bevel. Cavity etching was done by using 37\% phosphate acid on the email for 15 seconds and 10 seconds on the dentin which had been prepared, and then it was rinsed with water. Tooth surface which had been etched was later smeared slightly with the fifth generation of bonding material (Stae, SDI) by using microbrush to the whole cavity. The wind was blown on the cavity for 2 seconds and curing using light curing unit for 10 seconds. Short fiber reinforced composite (EverX, GC) was applied on the cavity and it was curing for 20 seconds. The application of A2 color of pack- able composite resin used plastic instrument with cusp-by-cusp technique and was curing with for 20 seconds (Figure 6).

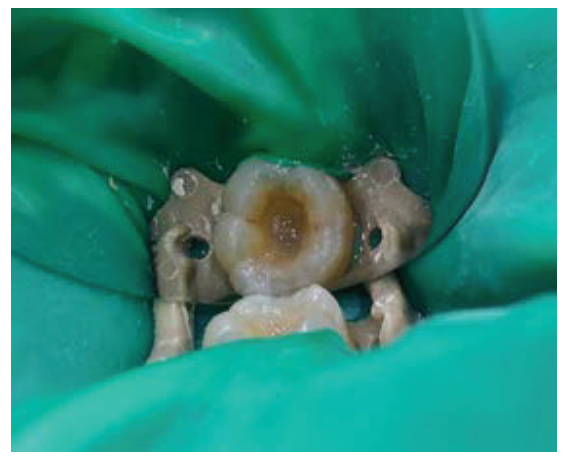

A

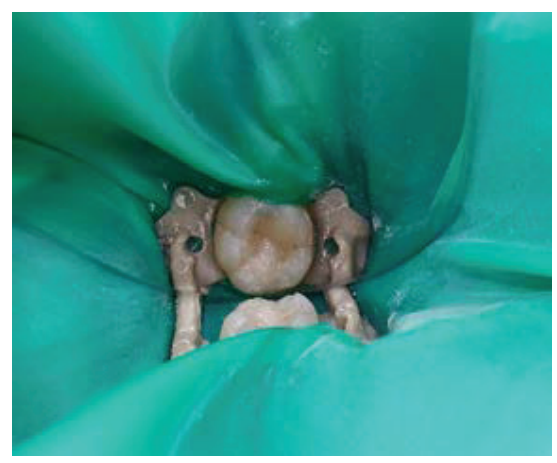

B

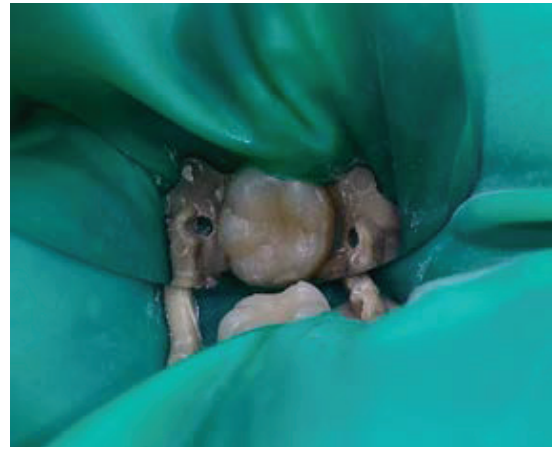

C

Figure 6

A. The application of short fiber reinforced composite; B and C. The applications of cusp-bycusp packable composite resin

Source: Personal Documentation (2018)

After the rubber dam was removed, occlusal checking was done with articulating paper. The traumatic part was reduced with a yellow-band pear shaped finishing bur. The 
finishing used fine flame finishing bur and polishing used polishing with astrobrush (Ivoclar). The patient was asked to come for check-up one week later.

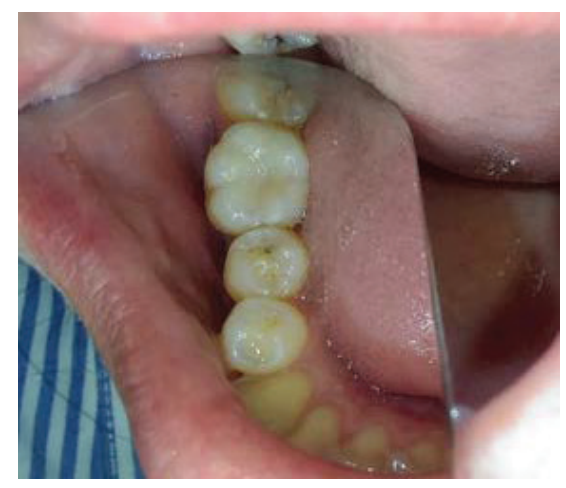

A

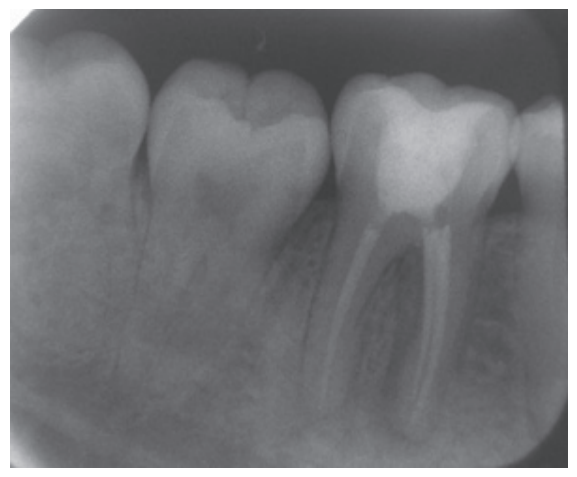

B

Figure 7.

A. Clinical illustration of finishing and polishing tooth; B. Radiographic illustration of restorated tooth

Source: Personal Documentation (2018)

On the fourth visit, the check-up for the restoration was done clinically and radiographically. The patient did not have any complaints and felt satisfied and comfortable with the tooth restoration. In the objective examination, it seemed that the adaptation of the composite resin restoration was good, the contour was good, there was no traumatic occlusion, there was no discoloration of the restoration, the health of the tooth supporting tissues was good, and there was no gingival inflammation. Percussion and palpation tests also showed negative results. In radiographic examination, radiolucent in the bi- furcation area had got smaller than the first visit (Figure 8). The patient was suggested to keep the dental and oral hygiene, so a periodical check-up to dentist could be done every 6 months.

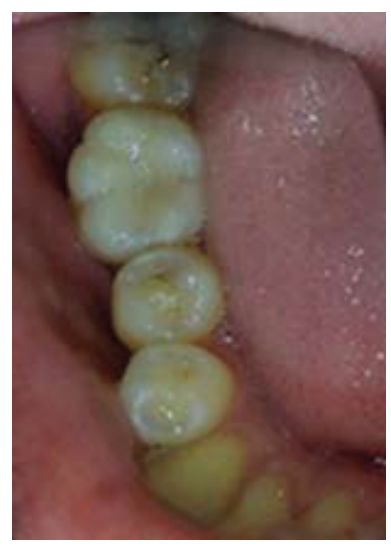

A

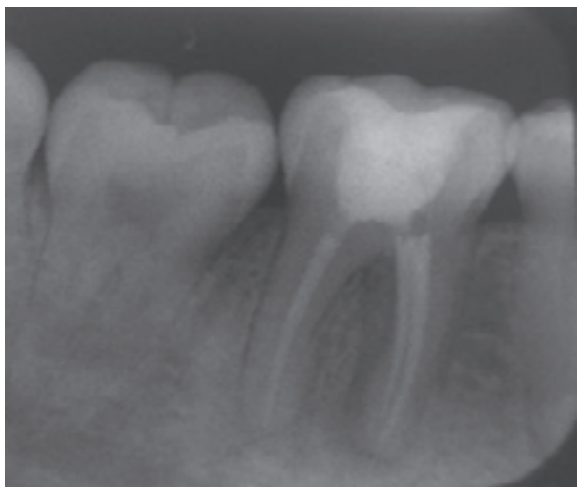

B

Figure 8

A. Clinical illustration of tooth on the check-up one week after the restoration; B. Radiographic illustration showing lesions in bifurcation and periapical have got smaller than the first visit.

Source: Personal Documentation (2018)

\section{RESULT AND DISCUSSION}

In this case, the right mandibular first molar was necrotic and there were lesions in the bifurcation and periapical areas and gumboil on the buccal mucosa of the tooth. The pulp tissue was necrotic as a result of secondary caries due to the microleakage of the restoration. The microleakage in a restoration will be an entry for bacteria and microorganisms. Bacteria will create acid atmosphere leading to demineralization on dental 
hard tissue. The process is getting wider and if it involves the area around the pulp, it will cause irritation and inflammation to the pulp tissue up to the death of the pulp tissue. The inflammation can penetrate periapical tissue so there is a body response to the inflammation such as vasodilation of blood vessel and leukocyte transmigration from the blood vessel to the perivaskuler to phagocytosis and to kill the microorganisms. The advanced inflammation will cause accumulation of inflamed cells and result in exudate, so abscess emerges. The exudate will find an exit to drainage and to create gumboil lesion on the gingiva (Cohen and Hargreaves, 2011; Walton and Torabinejad, 2003).

The preparation technique of the root canals used in this case was the crown down technique. This technique was used since it was expected that it could eradicate the constriction of coronal area, reduce the curvature of the root canals so we can get the free access to one-third of the apical area and the penetration of the irrigation liquid could be deeper. Debris and infected tissues that have been removed before one-third of the apical will reduce the risk of the push of debris to the apical (Harty, 1992).

In this case, irrigation combining sodium hipoklorit $(\mathrm{NaOCl}) 2,5 \%$ and ethylenediaminetetraacetic acid (EDTA) was used. The combination of both materials is usually recommended to remove the smear layer from the walls of the root canals (Tatsuka et.al., 1999). The concentration of sodium hipoklorit $2,5 \%$ is effective enough to help dissolve organic tissues due to wide spectrum antimicrobial characteristic and effective for anaerobic bacteria and facultative microorganism (Rodig et.al., 2011). However, it is not effective to remove the smear layer. Therefore, $\mathrm{NaOCl}$ and EDTA are used alternately in the irrigation after the preparation of the root canal (Johnson, 2011). Debridement with irrigation instruments and materials are important parts in the phase of root canal treatment (Desai and Himel, 2009).

In this case, the sterilization material used in the root canals was calcium hydrox- ide with glycerin as a mixing material which could be placed in the root canals to have direct contact with the walls of the root canals, so it enable the diffusion of the active components to the dentinal tubule and root canal walls. Calcium hydroxide is widely used as an intra-canal medication due to having antimicrobial characteristic which heals the inflammation of periapical tissue, dissolves organic tissues, restrains the inflammation resorption, stimulates the formation of hard tissues and functions as temporary filling material between the visits (Calisskan et.al., 1998).

The obturation used single cone technique with resin sealer. Obturation phase is an important phase because most of the failures in root canal treatment are cause by obturations which are not hermetic. It is important to create a perfect tightness along the root canals to create and to keep the sustainability of the coronal in order to keep the long term success of the root canal treatment (Walton and Torabinejad, 2003).

Final restoration in this case used packable composite resin with short fiber reinforced composite. In the tooth post root canal treatment, it will lose quite a lot dentin because the treatment reduce a lot dentin so the quantity of the dentin left to withstand the mastication pressure will reduce (Herrero et.al., 2005). Packable composite resin has more fillers so it is rigid and resilient to mastication pressure on the posterior teeth (Sajjan et.al., 2010). According to Garoushi et.al., (2015), the use of short fiber reinforced composite as combined with packable composite resin can result in lower micro gap compared to other materials. It is because of the fiber in the material which will absorb the stress during the polymerization and increase the stress release by the matrix so it reduces the micro gap risk on the marginal and increase the material adaptation.

\section{CONCLUSION}

The treatment of tooth 46 with necrotic pulp and gumboil can be successful by applying the endodontic triad principle, name- 
ly biomechanic preparation, sterilization and adequate root canals filling, so it will boost the healing of the surrounding tissues. To support the success of the root canal treatment in a long term, a restoration which is able to keep the coronal tightness is needed so it can prevent reinfection. Combination of composite resin restoration with fiber reinforced composite can improve the bond strength and increase the mastication strength for the posterior teeth.

\section{BIBLIOGRAPHY}

Caliskan, M.L., Turkun, M., and Turkun, L.S. 1998. Effect of Calcium Hydroxide as an Intracanal Dressing on Apical Leakage. International Endododontic Journal, 31: 173-177.

Cohen, S., and Hargreaves, K. 2011. Pathways of the pulp. St.Louis: Mosby.

Desai, P., and Himel, V. 2009. Comparative Safety of Various Intracanal Irrigation System, Journal Endododontic, 35: 545549.

Ellakwa, A.E., Shoetall, A.C., Shehata, M.K., and Marquis, P.M. 2002. Influence of Bonding Agent Composition on Flexural Properties of an Ultra High Molecular Weight Polyethilene Fiber Reinforced Composite. Operative Dentistry, 27: 184-91.

Garoushi, S.K., Hatem, M., Lassila, L.V.J., and Vallittu, P.K. 2015. The Effect of Short Fiber Composite Base on Microleakage and Load Bearing Capacity of Posterior Restoration, Acta Biomater Odontol Scand, 1(1): 6-12

Grossman, L.I., Oliet, S., and Del Rio, C.E. 1995. Ilmu Endodontik dalam praktek (terj.) ed.11, Jakarta, Penerbit Buku kedokteran EGC, h. 69, 93-96.

Harty, F.J. 1992. Endodontik Klinis (terj.) Third Edition, Jakarta: Hipokrates.
Herrero, A.A., Yaman, P., and Dennison, J.B. 2005. Polimerization Shrinkage and Depth of Curve of Packable Composite, Quintessence International, 36(1): 25-31.

Hui, K.C., Nah, N.C., Eng, T.K., Choon, E.L., Kian, C.L., and Chee, P.S. 2004. Guidelines for Root Canal Treatment, Singapore Dental Journal., 26(1): 60-62.

Johnson, K.L. 2011. A Comparison of The Effectiveness of Three Irrigation Methods in The Removal of Bacteria from Root Canals Following Instrumentation, Chapel Hill, p. 1-34.

Rodig, T., Hirscleb, M., Zapf, A., and Hulsmann, M. 2011. Comparison of Ultrasonic Irrigation and Rinse Endo for The Removal of Calcium Hydoxide and Ledermix Paste from Root Canals, International Endodontic Journal., 44: 1155-1161.

Sajjan, R.M.G.S., Kusmaraswarny, B.N., and Mittal, N. 2010. Effect of Different Placement Technique on Marginal Microleakage of Deep Class II Cavities Restored with Two Composite Resin Formulations. Journal Conservative Dentistry, 13(1): 9-15.

Tarigan, R., and Tarigan, G., 2012, Perawatan pulpa gigi (Endodonti), Third Edition. Jakarta: Penerbit Buku Kedokteran, EGC.

Tatsuka, C.T., Morgan, L.A., Baumgartner, J.C., and Adey, J.D. 1999. Effect of Calcium Hydroxide and Four Irrigation Regiments on Instrumented and Uninstrumented Canal Wall Topography. Journal Endodontic, 25(2): 9398.

Walton, R.E., and Torabinejad, M. 2003. Prinsip dan praktik ilmu endodonsia, Third Edition. Jakarta: Penerbit Buku Kedokteran EGC. 